\title{
Fetal Insulin and Growth Hormone
}

\section{Metabolism in the Subhuman Primate}

\author{
Daniel H. Mintz, Ronald A. Chez, and Edgar O. Horger III \\ From the Departments of Medicine and Obstetrics and Gynecology, University \\ of Pittsburgh School of Medicine and Magee-Womens Hospital, \\ Pittsburgh, Pennsylvania 15213
}

\begin{abstract}
A BSTRACT The concentrations of plasma glucose, insulin, growth hormone, and immunoreactive growth hormone-like substance in subhuman primate fetal and maternal plasma were examined after the intravascular administration of glucose, arginine, or tolbutamide to the fetus. Cannulation of interplacental vessels permitted studies on the fetus in utero without disruption of fetalplacental-maternal anatomic integrity. Single glucose injections, glucose infusions, and arginine infusions into the fetus did not alter fetal plasma insulin concentrations. In contrast, tolbutamide injections elicited an immediate 3-4-fold increase in fetal plasma insulin concentrations. A bidirectional placental transfer of insulin was demonstrated with the use of simultaneously injected insulin- ${ }^{125} \mathrm{I}$ to the mother and insulin $-{ }^{131} \mathrm{I}$ to the fetus.
\end{abstract}

Simian fetal plasma contained a substance which crossreacted with immunologic identity to human growth hormone. In contrast, simian maternal plasma and amniotic fluid reacted with immunologic nonidentity to human growth hormone. Although glucose administration to the fetus did not suppress nor did arginine infusion consistently augment fetal plasma growth hormone levels, the latter were observed to vary in individual experiments.

The plasma responses to the same stimuli in the neonate were also examined. In contrast to the fetal experiments, glucose injection in the neonate elicited a delayed rise in the concentration of plasma insulin. Similar to the fetus, the plasma concentration of insulin increased after tolbutamide injection and did not change in response to arginine infusion. The initial concentrations of neonatal plasma growth hormone were significantly lower when contrasted with the initial fetal plasma levels. There was no difference in the responsiveness of the fetal and neonatal growth hormone-

Received for publication 25 July 1968 and in revised form 16 September 1968. releasing mechanisms when challenged by glucose or arginine infusion.

The data indicate that the fetal plasma concentration of growth hormone is labile, that fetal growth hormone metabolism may differ from that in the neonate, and that pancreatic islet cell responsiveness rapidly changes after delivery.

\section{INTRODUCTION}

Numerous studies have provided data (1-9) on the concentrations of glucose, insulin, and growth hormone in human umbilical cord and maternal plasma at the time of delivery. Such data, however, obtained during the altered metabolic states occurring just before or immediately after delivery do not allow inferences to be drawn concerning fetal function earlier in pregnancy. Antenatal investigations of plasma glucose, insulin, and growth hormone interrelationships in the primate fetalplacental-maternal unit have not been reported.

This study was undertaken to investigate sequential changes in the concentrations of plasma glucose, insulin, and growth hormone in primate fetal and maternal plasma after the intravascular administration of glucose, arginine, or tolbutamide to the fetus. The experimental technique involved cannulation of, and blood sampling from, interplacental fetal vessels in the pregnant monkey (Macaca mulatta). The use of this animal as a model for placental transfer and fetal metabolic studies has been previously described (10-13). In an attempt to define any modifying influence of the placenta on fetal plasma responses, the bidirectional placental transfer of radioisotopically labeled insulin, and the neonatal plasma responses to the same stimuli were examined.

\section{METHODS}

Surgical techniques. Pregnant rhesus monkeys (Macaca mulatta) with accurately known gestational ages were pur- 
chased from Bionetics Research Laboratories, Kensington, Md. The duration of pregnancy ranged from 140 to 149 days in all but one instance of 110 days. The gestation period for this particular colony is $164 \pm 7$ days. The animals were maintained on biscuits (Purina Monkey Chow) and water ad lib. until they were fasted for the $12 \mathrm{hr}$ before surgery. In the animals in which radioactive iodine was used, 15 drops of Lugol's solution was administered orally 12 and $3 \mathrm{hr}$ before the experiment.

After premedication with intramuscular phencyclidine hydrochloride, $1 \mathrm{mg} / \mathrm{kg}$ body weight, and $0.4 \mathrm{mg}$ atropine sulfate, the mother was placed on thermal pads in a supine position approximately $20^{\circ}$ above the horizontal with her forelimbs adducted. Halothane $(0.5-1.0 \%)$ and oxygen were administered through an endotracheal tube by an anesthetist. After exposing the pregnant uterus through a lower midline laparotomy, fetal heart tones were monitored with a detector utilizing the Doppler principle (Ames Co., Inc., Elkhart, Indiana). Fetal bradycardia occurred in only one experiment. Uterine contractions were observed infrequently during the surgical procedures.

The majority of pregnancies in this species are associated with bidiscoid placentas. The umbilical cord inserts into the primary placenta, and interplacental vessels from the cord run between the amnion and chorion to the secondary placenta. As described by Reynolds, Paul, and Huggett (10), these vessels were located by candling the uterus. After selecting an interplacental vessel, a $1.5 \mathrm{~cm}$ incision was made in the overlying myometrium, decidua, and chorion, but not amnion. The exposed vessel, a fetal artery or vein, was then cannulated with a silicone rubber T tube I.D. 0.032", O.D. 0.052" (Extracorporeal Systems, Inc., New Brunswick, N. J.). This $T$ tube permitted both continuous flow through the vessel and sequential sampling of fetal blood while the fetus remained in utero in the intact amniotic sac. When the myometrial incision was on the anterior wall of the uterus, the uterus could remain in the abdominal cavity. In other instances, a moistened plastic bag was placed over the uterus to minimize dessication, and external heat was supplied with an infrared lamp.

Amniotic fluid was obtained through a plastic catheter secured in the amniotic cavity. Maternal blood was sampled through a cannula placed into the thoracic vena cava from insertion at a saphenous vein. Maternal blood samples were approximately $3.0 \mathrm{ml}$ in volume; fetal blood samples did not exceed $1.1 \mathrm{ml}$. These aliquots of blood were replaced with equal volumes of heparin-normal saline ( 5 units $/ \mathrm{ml}$ ). Hematocrits were determined at the beginning and end of the experiment. The initial maternal hematocrit ranged from $37-44 \%$ with a mean of $41 \%$, and that of the fetus ranged from $36-43 \%$ with a mean of $41 \%$. The maximum decreases in the concentration of red blood cells did not exceed $5 \%$ of the original value for the mother and, with one exception, $15 \%$ for the fetus.

At the end of the experiment, the fetus was delivered and weighed, the umbilical vein was cannulated, and the newborn was then transferred to the nursery for supportive care. The neonates were fed $2 \mathrm{ml}$ of $5 \%$ dextrose and water every $4 \mathrm{hr}$ after delivery. Between 4 and $22 \mathrm{hr}$ of life, and after at least a $4 \mathrm{hr}$ fast, experiments were performed on vigorous and clinically healthy neonates through the cannulated umbilical vein. The neonates were undisturbed by these studies and generally slept through most of the procedures in heated bassinets.

Placental transfer studies. The placental transfer of insulin was studied in four animals. Purified porcine insulin (Eli Lilly \& Co., Indianapolis, Indiana) was labeled to specific activities of $200-400 \mu \mathrm{c} / \mu \mathrm{g}$ with either ${ }^{125} \mathrm{I}$ or ${ }^{131} \mathrm{I}$ by the method of Hunter and Greenwood (14). The iodination mixture was purified of damaged products and free radioactive iodine by passage through a cellulose column; the iodinated insulin was eluted from the column with iodoacetamide-treated human plasma (15). This eluate, diluted in rhesus monkey plasma, was subjected to hydrodynamic flow chromatoelectrophoresis (15) and to double antibody precipitation by a technique to be described. On the days of the isotope injections, $90 \%-92 \%$ of the iodinated insulin remained at the chromatogram origin and $85 \%-87 \%$ of the radioactivity was immunoprecipitable.

The bidirectional placental transfer of insulin was examined after the simultaneous injections of insulin- ${ }^{125} \mathrm{I}$ into the maternal vena cava and insulin- ${ }^{131} \mathrm{I}$ into the fetal interplacental vein. The amount of radioactivity per injection varied from 75 to $107 \mu \mathrm{c}$; the amount of labeled insulin injected did not exceed 0.002 units insulin $/ \mathrm{kg}$ of total body weight. Intermittent blood specimens were withdrawn simultaneously into heparinized syringes from the fetal and maternal circulations after the injections of the radioisotopically labeled insulin. Immediately thereafter, the plasma was separated and frozen at $-20^{\circ} \mathrm{C}$. These samples were analyzed in duplicate by a modification of the double antibody precipitation technique (16).

$0.2-\mathrm{ml}$ aliquots of plasma in $0.1 \mathrm{ml}$ of $0.1 \mathrm{M}$ Ethylenediaminetetraacetic acid (EDTA) were incubated with 0.2 $\mathrm{ml}$ guinea pig anti-insulin serum $(1: 2000)$ for $48 \mathrm{hr}$ at $4^{\circ} \mathrm{C}$ Then, $0.1 \mathrm{ml}$ rabbit anti-guinea pig globulin (Hyland Laboratories, Los Angeles, Calif.) and $0.1 \mathrm{ml}$ normal guinea pig plasma were added and the mixture was incubated for an additional $24 \mathrm{hr}$ at $4^{\circ} \mathrm{C}$. After centrifugation, the supernate was decanted and the precipitate was washed twice with $0.5 \mathrm{ml}$ Veronal buffer, $\mathrm{pH}$ 8.6. Ioresin, $2 \mathrm{mg}$ (Abbott Laboratories, North Chicago, Ill.), was then added to the combined wash and supernate. After $30 \mathrm{~min}$, this supernate was removed with a capillary pipette and the resin pellet was washed twice with Veronal buffer. The radioactive counts in the immunoprecipitate, the Ioresin pellet, and the combined washes and supernate were counted separately in a gamma scintillation counter to a statistical error of less than $2 \%$. All counts were corrected for background, decay, and volume. Plasma volume equivalents were obtained by correcting for any existing hematocrit differences between maternal and fetal pools. In the bidirectional flow studies, ${ }^{131} \mathrm{I}$ was counted in a window free of ${ }^{125} \mathrm{I}$ overflow. ${ }^{125} \mathrm{I}$ was then counted without overflow contamination after allowing ${ }^{131} \mathrm{I}$ to decay to an insignificant level.

The validity of this Ioresin double antibody precipitation method for separation of immunoreactive radioisotopically labeled insulin (immunoprecipitable counts), insulin degradation products (supernate plus wash counts), and free iodine, as iodide ion, (Ioresin pellet counts), was investigated. Aliquots of monkey plasma containing variable quantities of insulin- ${ }^{131} \mathrm{I}$, degraded ${ }^{131} \mathrm{I}$-labeled insulin products, and free iodine- ${ }^{131} \mathrm{I}$ were submitted both to Ioresin double antibody precipitation and hydrodynamic flow chromatoelectrophoresis and the results were compared.

Endocrine stimulation studies. The fetal and simultaneous maternal plasma glucose, immunoreactive insulin, and immunoassayable growth hormone responses to single glucose injections ( $2 \mathrm{ml}$ of $12.5 \%$ glucose in Ringer's lactate), glucose infusions (10 and $20 \mathrm{mg}$ glucose/min for $120 \mathrm{~min}$ ), arginine infusions $(10 \%$ arginine monohydrochloride, 10 $\mathrm{mg} / \mathrm{min}$ for $30 \mathrm{~min})$, and tolbutamide injections (1.25 and $2.5 \mathrm{ml}$ of $2 \%$ tolbutamide in $0.9 \%$ saline) were examined. In 11 experiments, blood samples were withdrawn simul- 
TABLE I

Comparison of Hydrodynamic Flow Chromatoelectrophoresis and Ioresin Double Antibody Precipitation Techniques for Labeled Insulin and Products in Monkey Plasma

\begin{tabular}{crcrc}
\hline & & \multicolumn{3}{c}{$\%$ of total 111 counts } \\
\cline { 3 - 5 } Plasma & Method & Insulin & $\begin{array}{c}\text { Damaged } \\
\text { products }\end{array}$ & $\begin{array}{c}\text { Free iodine } \\
\text { (as iodide } \\
\text { ion) }\end{array}$ \\
\cline { 3 - 6 } A & Chromatoelectrophoresis & 87.1 & 8.6 & 4.3 \\
& Ioresin-double antibody & 82.0 & 12.8 & 5.2 \\
\multirow{2}{*}{ B } & Chromatoelectrophoresis & 43.2 & 36.6 & 20.2 \\
& Ioresin-double antibody & 39.1 & 41.3 & 19.6 \\
C & Chromatoelectrophoresis & 12.6 & 0.0 & 87.4 \\
& Ioresin-double antibody & 8.4 & 2.4 & 89.2 \\
\hline
\end{tabular}

taneously from the fetal and maternal circulations before and at intermittent time intervals after the injections or infusions. In eight additional experiments, neonatal blood samples were obtained from the cannulated umbilical vein before and at intermittent time intervals after similar injections or infusions.

The plasma was separated immediately and frozen at $-20^{\circ} \mathrm{C}$ until analyzed in duplicate for glucose by the ferricyanide autoanalyzer technique and for insulin and growth hormone by a modification (17) of the coated charcoal immunoassay method of Herbert, Kam-Seng, Gottlieb, and Bleicher (18). Incubation of fetal, maternal, or neonatal plasma with glucose oxidase completely removed the reducing substances analyzed in the ferricyanide method. Inhibition of the binding of porcine insulin- ${ }^{131} I$ to antiserum to porcine insulin by the addition of increasing amounts of unlabeled simian insulin (gift from Dr. I. Arthur Mirsky) yielded an inhibition curve parallel to that obtained with the porcine standard used in the immunoassay. In additional control experiments, inhibition of the binding of human growth hormone- ${ }^{131}$ I (gift from National Pituitary Agency) to antiserum to human growth hormone by the addition of increasing amounts of unlabeled simian growth hormone (gift from Dr. Ernst Knobil and Dr. William Peckham) yielded an inhibition curve parallel to that obtained with the human growth hormone standard used in the immunoassay. Plasma growth hormone concentrations in nonpregnant rhesus monkeys were unaffected by the premedication and anesthesia employed in these studies.

Experiments were performed to assess the immunologic similarity of the cross-reacting substance in simian fetal and maternal plasma and amniotic fluid with the human growth hormone used as a standard in the immunoassays. Plasma or amniotic fluid was assayed for growth hormone at three or more dilutions and the slope of the inhibition of the binding of human growth hormone- ${ }^{131} \mathrm{I}$ to antiserum to human growth hormone was compared to that observed with unlabeled human growth hormone.

\section{RESULTS}

\section{Control studies}

Three preparations containing differing quantities of insulin- ${ }^{181} \mathrm{I}$, degraded insulin ${ }^{181} \mathrm{I}$ products, and free iodine $-{ }^{181} \mathrm{I}$ were incubated for $15 \mathrm{~min}$ in monkey plasma. Aliquots of the plasmas were submitted to both hydrodynamic flow chromatoelectrophoresis and Ioresin double antibody precipitation. The results, depicted in Table I, demonstrate a close agreement between the two techniques for the detection of these radioactive-labeled substances in monkey plasma. Since the simultaneous bidirectional transfer studies required the distinction between insulin ${ }^{-125} I$ and insulin ${ }^{181} I$ and their products, the Ioresin double antibody precipitation method was selected.

Fig. 1 depicts the slopes of inhibition of the binding of human growth hormone- ${ }^{181} \mathrm{I}$ to antiserum to human growth hormone after the addition to the incubation mixture of human growth hormone, simian maternal plasma, simian fetal plasma, or simian amniotic fluid. Parallelism between the inhibition curves obtained from

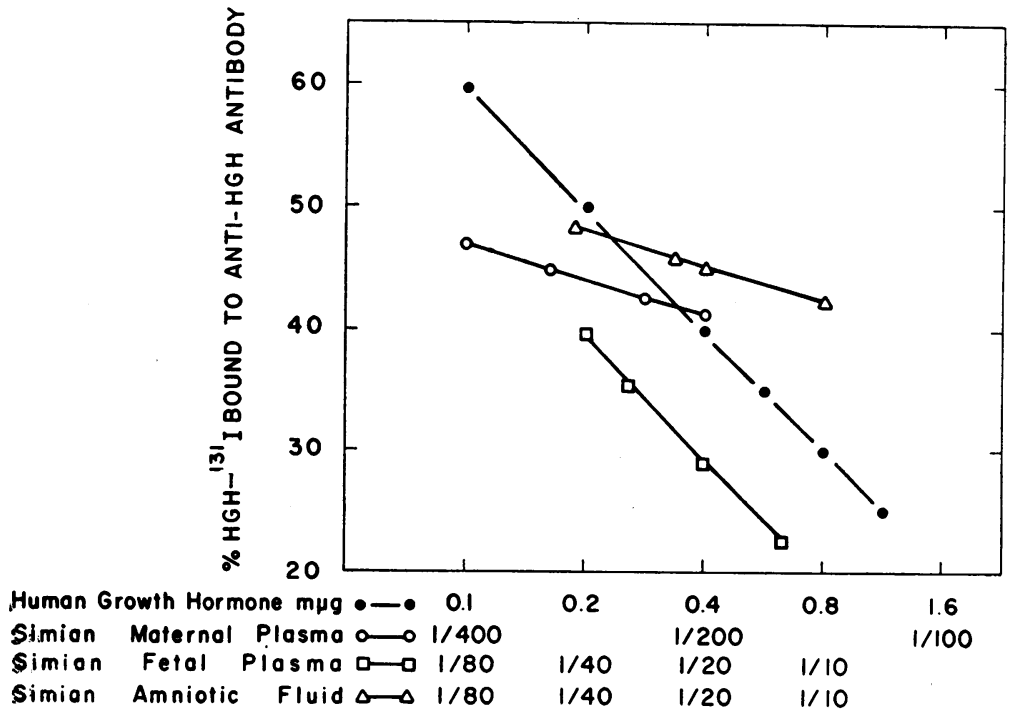

FIgURE 1 Inhibition of the binding of human growth hormone-131 I to antihuman growth hormone antiserum after the addition of either human growth hormone, simian maternal plasma, fetal plasma, or amniotic fluid to the incubation mixtures. 


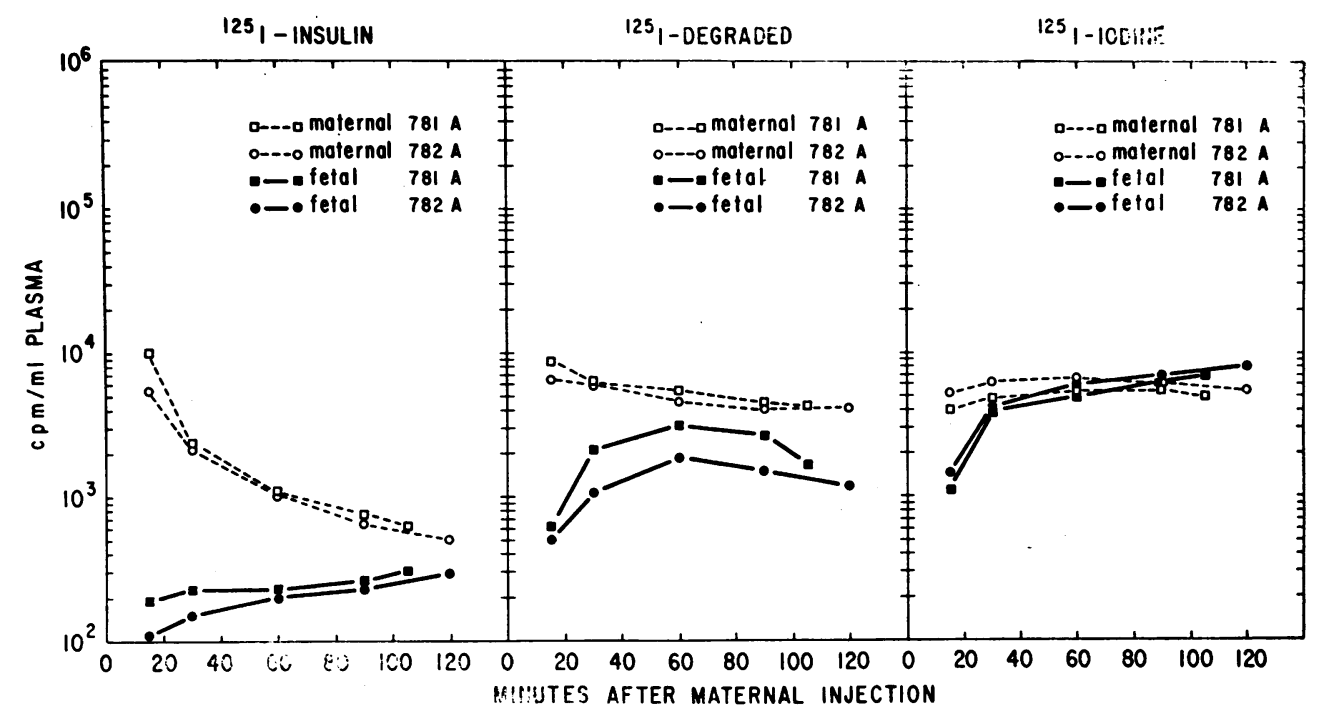

FIGURE 2 Relation between maternal and fetal plasma insulin- ${ }^{125} \mathrm{I}$, degraded insulin- ${ }^{125} \mathrm{I}$ products, and free iodine- ${ }^{125} \mathrm{I}$ concentration after maternal insulin- ${ }^{125} \mathrm{I}$ injection. The fetus received simultaneously an insulin ${ }^{131} \mathrm{I}$ injection. See Fig. 3.

human growth hormone and simian fetal plasma provided evidence that the simian fetal plasma contained growth hormone or a substance immunologically similar to it. In contrast, reduced slopes of inhibition were obtained with simian maternal plasma and simian amniotic fluid. These samples contained a growth hormone-like substance which partially cross reacted with antiserum to human growth hormone but was not immunologically identical to the human growth hormone standard.

\section{Placental transfer studies}

Radioactive-labeled insulin was injected simultaneously into the maternal (insulin- ${ }^{125} \mathrm{I}$ ) and fetal (insulin$\left.{ }^{181} \mathrm{I}\right)$ circulations of two animals of 143 days gestation. The maternal to fetal immunoreactive insulin concentration ratios in plasma obtained before the injection were 2.2:0.7 (781A) and 1.4:0.6 (782A). Figs. 2 and 3 depict the disappearance and appearance curves of radioactive iodine-labeled insulin, degraded products, and free iodine (iodide ion) over $2 \mathrm{hr}$ of sampling. Insulin crosses bidirectionally. The maternal to fetal exchange of insulin was associated with steadily decreasing radioactive-labeled insulin concentration ratios, convergent and then divergent curves for the degraded products, and a reversal of the free iodine gradient (Fig. 2). When the fetus was the primary compartment, the count ratio of maternal to fetal radioactive-labeled insulin never exceeded $1 \%$; the curves for the degraded products converged, and the free iodine gradient reached an equilibrium at $10 \%$ (Fig. 3 ). In two other experiments not shown, the unidirectional maternal to fetal exchange of insulin labeled with ${ }^{181} \mathrm{I}$ was comparable to the data obtained with insulin ${ }^{120} \mathrm{I}$.

\section{Endocrine stimulation studies}

Glucose stimulation. The fetal and maternal plasma glucose, insulin, growth hormone, and immunoreactive growth hormone-like responses to glucose administration to the fetus are shown in Table II.

$5 \mathrm{~min}$ after the injection of $250 \mathrm{mg}$ of glucose into a fetal interplacental vein $(380 \mathrm{~A}, 64 \mathrm{C}, 476 \mathrm{C})$, the fetal plasma glucose rose by a mean increment of $109 \mathrm{mg} / 100$ $\mathrm{ml}$ and reversed the maternal-fetal glucose gradients. After this rise, the plasma glucose levels steadily declined as the maternal glucose concentrations rose, but the reversed glucose gradients persisted to the termination of the experiments. In two of the three experiments, the fall in fetal plasma glucose was not accompanied by a change in fetal plasma insulin concentration (380A, 64C). A slight rise in fetal plasma insulin concentration was observed in the 20 min sample of experiment $476 \mathrm{C}$. A $260 \%$ increase in maternal plasma insulin concentration preceded and may be responsible for this small increment in fetal plasma insulin concentration. Fetal plasma growth hormone levels did not change during fetal hyperglycemia. Subsequently, however, an increase was observed in two of three experiments (380A, 476C). The maternal plasma immunoreactive growth hormone-like levels remained constant throughout the experiments.

The intravenous injection of $250 \mathrm{mg}$ glucose into two neonates $(134 \mathrm{~N}, 588 \mathrm{~N})$ resulted in sustained elevations 
of the plasma glucose concentrations for $30 \mathrm{~min}$ (Table II), but no change in plasma insulin concentration was observed. The plasma growth hormone concentrations were relatively stable during the persistent hyperglycemia. In two neonates $(820 \mathrm{~N}, 298 \mathrm{~N})$, umbilical venous blood was obtained at $30 \mathrm{~min}$ intervals for $120 \mathrm{~min}$ after the glucose injections. In both experiments, a definite rise in plasma insulin concentration was observed in the specimen obtained $60 \mathrm{~min}$ after the glucose injection. In the oldest neonate $(298 \mathrm{~N})$, an increase in plasma insulin concentration was evident $30 \mathrm{~min}$ after the glucose injection. Plasma growth hormone concentrations rose sharply during the last $60 \mathrm{~min}$ of these experiments.

Since a delayed plasma insulin response to a persistent hyperglycemia did appear in the neonate, two additional experiments were performed to determine whether the fetus would also demonstrate a delayed release of insulin. In these experiments $(283 \mathrm{C}, 602 \mathrm{C}$, Table II), the glucose solution was infused intravenously at a constant rate for $120 \mathrm{~min}$ after the initial glucose injection. The constant rate of glucose infusion produced a persistent fetal hyperglycemia throughout the experiment in spite of the transfer of glucose from the fetus to the mother. Fetal plasma insulin concentrations, however, remained unchanged. Fetal plasma growth hormone concentrations rose in the last $60 \mathrm{~min}$ of experiment $283 \mathrm{C}$, but remained relatively constant in experiment $602 \mathrm{C}$.

Arginine stimulation. The fetal and maternal plasma glucose, insulin, growth hormone, and immunoreactive growth hormone-like responses to fetal arginine infusion are detailed in Table III. The fetal and maternal plasma concentrations remained relatively constant during ( 0 through $30 \mathrm{~min}$ ) and after (31 through $60 \mathrm{~min}$ ) the arginine infusion in $642 \mathrm{C}$ and $411 \mathrm{C}$. In experiment 298C, the uterus contracted at irregular intervals for the last $30 \mathrm{~min}$ of the experiment. During this time, there was a rise in fetal plasma glucose and growth hormone concentrations; plasma insulin levels were unchanged. Subsequently, at $22 \mathrm{hr}$ after birth this fetus, as a neonate, released insulin upon receiving $250 \mathrm{mg}$ glucose intravenously (Table II).

Two neonatal responses to intravenous arginine infusions are also detailed in Table III. The neonatal plasma glucose and insulin concentrations were unchanged during or after the arginine infusion. One of these animals (642N) was similarly unresponsive to arginine infusion in utero. Plasma growth hormone concentrations rose slightly in the last $30 \mathrm{~min}$ of both experiments.

Tolbutamide stimulation. The fetal and maternal plasma glucose, insulin, growth hormone, and immunoreactive growth hormone-like responses to an intravenous injection of tolbutamide are detailed in Table IV. 2 min after the injection, there was a 3 to 4 -fold increase in fetal plasma insulin concentration in experiments $588 \mathrm{C}$ and $452 \mathrm{C}$. The maternal plasma insulin concentrations did not change until $10 \mathrm{~min}$ after the injection. The increase in fetal plasma insulin concentration was not accompanied by a fall in the fetal plasma glucose concentration. In both experiments, the maternal plasma glucose gradually rose.

In an attempt to define when an insulinogenic response to tolbutamide would first be evident in preg-

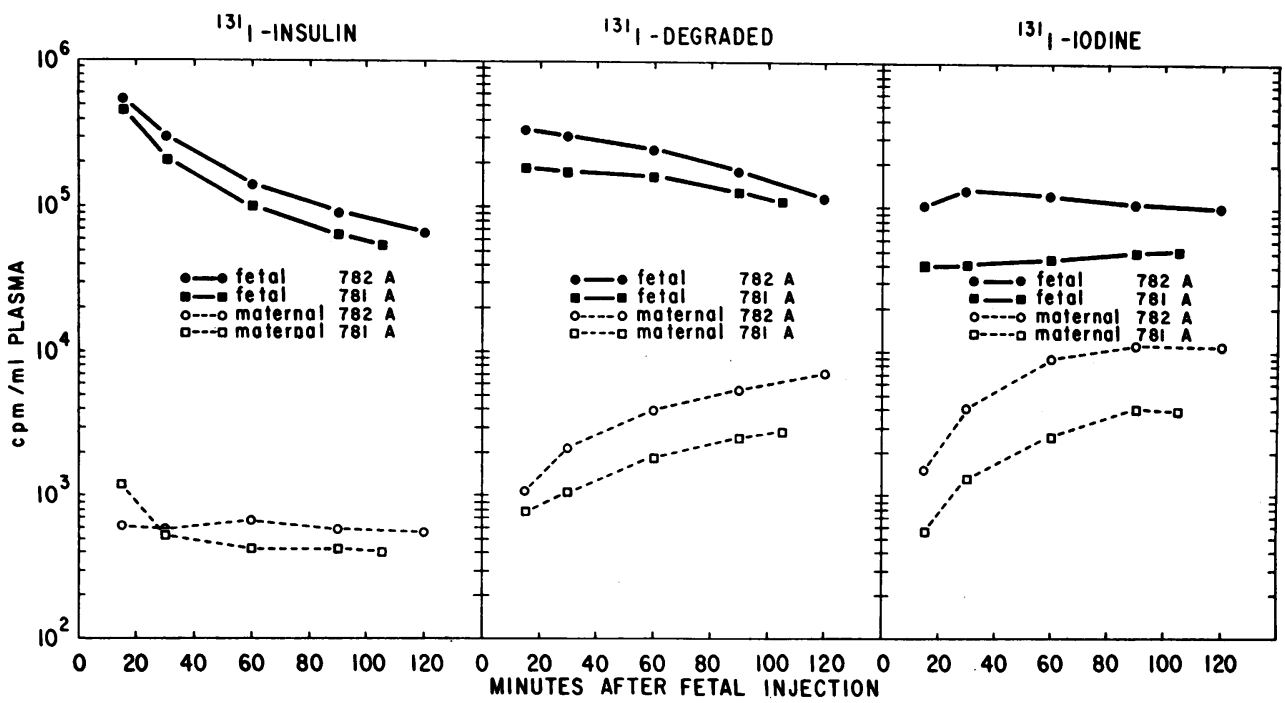

Figure 3 Relation between fetal and maternal insulin- ${ }^{131} \mathrm{I}$, degraded insulin- ${ }^{181} \mathrm{I}$ products, and iodine- ${ }^{131} \mathrm{I}$ concentrations after fetal ${ }^{181} \mathrm{I}$ injection. The mother received simultaneously a ${ }^{125} \mathrm{I}$ injection. See Fig. 2. 
TABLE II

Effect of Intravenous Glucose Administration to the Fetus or Neonate on the Plasma Glucose,

Insulin, Growth Hormone, and Immunoreactive Growth Hormone-like Concentrations

\begin{tabular}{|c|c|c|c|c|c|c|c|c|c|c|c|c|c|}
\hline \multirow[b]{2}{*}{ Animal } & \multirow[b]{2}{*}{ Amount } & \multirow[b]{2}{*}{ Site } & \multirow{2}{*}{$\begin{array}{c}\text { Plasma } \\
\text { assay }\end{array}$} & \multicolumn{9}{|c|}{ Time (Min) } & \multirow[b]{2}{*}{ Comment } \\
\hline & & & & 0 & 5 & 10 & 15 & 20 & 30 & 60 & 90 & 120 & \\
\hline \multirow[t]{2}{*}{$380 \mathrm{~A}$} & $\begin{array}{l}250 \mathrm{mg} \text { glucose in- } \\
\text { jected at } 0^{\prime}\end{array}$ & Fetal vein & $\begin{array}{l}\text { CHO* } \\
\text { INS } \ddagger \\
\text { GH\& }\end{array}$ & $\begin{array}{c}43 \\
0.4 \\
14\end{array}$ & $\begin{array}{c}141 \\
0.4 \\
13\end{array}$ & $\begin{array}{c}100 \\
0.4 \\
14\end{array}$ & & $\begin{array}{c}84 \\
0.4 \\
17\end{array}$ & $\begin{array}{c}79 \\
0.4 \\
24\end{array}$ & & & & $\begin{array}{l}142 \text { day gestation, } \\
\text { mother } 6.5 \mathrm{~kg} \text {, male } \\
\text { fetus } 0.39 \mathrm{~kg} \text {, pla- } \\
\text { centa } 0.12 \mathrm{~kg}\end{array}$ \\
\hline & & $\begin{array}{l}\text { Maternal } \\
\text { vena cava }\end{array}$ & $\begin{array}{l}\text { CHO } \\
\text { INS } \\
\text { GHL }\end{array}$ & $\begin{array}{c}68 \\
0.9 \\
73\end{array}$ & $\begin{array}{l}90 \\
1.3 \\
70\end{array}$ & $\begin{array}{c}85 \\
1.4 \\
79\end{array}$ & & $\begin{array}{l}79 \\
1.0 \\
73\end{array}$ & $\begin{array}{c}77 \\
0.9 \\
73\end{array}$ & & & & \\
\hline \multirow[t]{2}{*}{$64 \mathrm{C}$} & $\begin{array}{l}250 \mathrm{mg} \text { glucose in- } \\
\text { jected at } 0^{\prime}\end{array}$ & Fetal vein & $\begin{array}{l}\text { CHO } \\
\text { INS } \\
\text { GH }\end{array}$ & $\begin{array}{c}45 \\
0.9 \\
35\end{array}$ & $\begin{array}{c}150 \\
0.8 \\
37\end{array}$ & $\begin{array}{c}120 \\
0.8 \\
37\end{array}$ & & $\begin{array}{c}114 \\
0.7 \\
37\end{array}$ & $\begin{array}{l}95 \\
0.8 \\
37\end{array}$ & & & & $\begin{array}{l}146 \text { day gestation, } \\
\text { mother } 9.0 \mathrm{~kg} \text {, fe- } \\
\text { male fetus } 0.42 \mathrm{~kg} \text {, } \\
\text { placenta } 0.13 \mathrm{~kg}\end{array}$ \\
\hline & & $\begin{array}{l}\text { Maternal } \\
\text { vena cava }\end{array}$ & $\begin{array}{l}\text { CHO } \\
\text { INS } \\
\text { GHL }\end{array}$ & $\begin{array}{c}61 \\
2.4 \\
93\end{array}$ & $\begin{array}{l}95 \\
3.4 \\
96\end{array}$ & $\begin{array}{l}93 \\
3.2 \\
94\end{array}$ & & $\begin{array}{l}92 \\
3.2 \\
92\end{array}$ & $\begin{array}{l}90 \\
2.5 \\
94\end{array}$ & & & & \\
\hline \multirow[t]{2}{*}{$476 \mathrm{C}$} & $\begin{array}{l}250 \mathrm{mg} \text { glucose in- } \\
\text { jected at } 0^{\prime}\end{array}$ & Fetal vein & $\begin{array}{l}\text { CHO } \\
\text { INS } \\
\text { GH }\end{array}$ & $\begin{array}{c}65 \\
0.4 \\
32\end{array}$ & $\begin{array}{c}191 \\
0.4 \\
27\end{array}$ & $\begin{array}{c}165 \\
0.4 \\
31\end{array}$ & & $\begin{array}{c}127 \\
0.8 \\
30\end{array}$ & $\begin{array}{c}106 \\
0.6 \\
43\end{array}$ & & & & $\begin{array}{l}148 \text { day gestation, } \\
\text { mother } 7.6 \mathrm{~kg} \text {, fe- } \\
\text { male fetus } 0.34 \mathrm{~kg} \text {, } \\
\text { placenta } 0.11 \mathrm{~kg}\end{array}$ \\
\hline & & $\begin{array}{l}\text { Maternal } \\
\text { vena cava }\end{array}$ & $\begin{array}{l}\text { CHO } \\
\text { INS } \\
\text { GHL }\end{array}$ & $\begin{array}{l}78 \\
2.4 \\
63\end{array}$ & $\begin{array}{l}94 \\
2.5 \\
62\end{array}$ & $\begin{array}{c}103 \\
6.4 \\
63\end{array}$ & & $\begin{array}{l}90 \\
6.0 \\
63\end{array}$ & $\begin{array}{l}74 \\
2.6 \\
60\end{array}$ & & & & \\
\hline \multirow[t]{2}{*}{$283 \mathrm{C}$} & $\begin{array}{l}250 \mathrm{mg} \text { glucose in- } \\
\text { jected at } 0^{\prime} 15 \mathrm{mg} / \\
\text { min glucose infused } \\
\text { trom } 0^{\prime} 120^{\prime}\end{array}$ & Fetal vein & $\begin{array}{l}\text { CHO } \\
\text { INS } \\
\text { GH }\end{array}$ & $\begin{array}{c}59 \\
0.6 \\
16\end{array}$ & & & $\begin{array}{c}340 \\
0.5 \\
16\end{array}$ & & $\begin{array}{c}335 \\
0.6 \\
17\end{array}$ & $\begin{array}{c}322 \\
0.6 \\
15\end{array}$ & $\begin{array}{c}319 \\
0.5 \\
20\end{array}$ & $\begin{array}{l}325 \\
0.5 \\
27\end{array}$ & $\begin{array}{l}147 \text { day gestation, } \\
\text { mother } 7.8 \mathrm{~kg} \text {, fe- } \\
\text { male fetus } 0.42 \mathrm{~kg} \text {. } \\
\text { placenta } 0.14 \mathrm{~kg}\end{array}$ \\
\hline & & $\begin{array}{l}\text { Maternal } \\
\text { vena cava }\end{array}$ & $\begin{array}{l}\text { CHO } \\
\text { INS } \\
\text { GHL }\end{array}$ & $\begin{array}{c}68 \\
1.5 \\
90\end{array}$ & & & $\begin{array}{l}78 \\
2.0 \\
94\end{array}$ & & $\begin{array}{c}146 \\
4.0 \\
90\end{array}$ & $\begin{array}{c}131 \\
2.9 \\
94\end{array}$ & $\begin{array}{c}113 \\
2.5 \\
94\end{array}$ & $\begin{array}{l}110 \\
1.3 \\
92\end{array}$ & \\
\hline \multirow[t]{2}{*}{$602 \mathrm{C}$} & $\begin{array}{l}250 \mathrm{mg} \text { glucose in- } \\
\text { jected at } 0^{\prime} 10 \mathrm{mg} / \\
\text { min glucose infused } \\
\text { from } 0^{\prime} 120^{\prime}\end{array}$ & Fetal vein & $\begin{array}{l}\text { CHO } \\
\text { INS } \\
\text { GH }\end{array}$ & $\begin{array}{c}62 \\
0.6 \\
28\end{array}$ & & & $\begin{array}{c}220 \\
0.6 \\
27\end{array}$ & & $\begin{array}{c}218 \\
0.7 \\
29\end{array}$ & $\begin{array}{c}200 \\
0.6 \\
28\end{array}$ & $\begin{array}{c}186 \\
0.6 \\
30\end{array}$ & $\begin{array}{c}196 \\
0.6 \\
31\end{array}$ & $\begin{array}{l}148 \text { day gestation, } \\
\text { mother } 6.8 \mathrm{~kg} \text {, male } \\
\text { fetus } 0.43 \mathrm{~kg} \text {, pla- } \\
\text { centa } 0.13 \mathrm{~kg}\end{array}$ \\
\hline & & $\begin{array}{l}\text { Maternal } \\
\text { vena cava }\end{array}$ & $\begin{array}{l}\text { CHO } \\
\text { INS } \\
\text { GHL }\end{array}$ & $\begin{array}{c}72 \\
1.1 \\
95\end{array}$ & & & $\begin{array}{l}75 \\
1.7 \\
97\end{array}$ & & $\begin{array}{l}81 \\
1.7 \\
99\end{array}$ & $\begin{array}{l}86 \\
1.8 \\
96\end{array}$ & $\begin{array}{l}76 \\
1.7 \\
90\end{array}$ & $\begin{array}{l}67 \\
1.2 \\
88\end{array}$ & \\
\hline $134 \mathrm{~N}$ & $\begin{array}{l}250 \mathrm{mg} \text { glucose in- } \\
\text { jected at } 0^{\prime}\end{array}$ & $\begin{array}{l}\text { Umbilical } \\
\text { vein }\end{array}$ & $\begin{array}{l}\text { CHO } \\
\text { INS } \\
\text { GH }\end{array}$ & $\begin{array}{l}57 \\
0.4 \\
7\end{array}$ & $\begin{array}{c}248 \\
0.5 \\
10\end{array}$ & $\begin{array}{c}218 \\
0.5 \\
8\end{array}$ & & $\begin{array}{c}210 \\
0.5 \\
7\end{array}$ & $\begin{array}{c}199 \\
0.5 \\
7\end{array}$ & & & & $\begin{array}{l}18 \mathrm{hr} \text { of life, male } 0.46 \\
\mathrm{~kg}\end{array}$ \\
\hline $588 \mathrm{~N}$ & $\begin{array}{l}250 \mathrm{mg} \text { glucose in- } \\
\text { jected at } 0^{\prime}\end{array}$ & $\begin{array}{l}\text { Umbilical } \\
\text { vein }\end{array}$ & $\begin{array}{l}\text { CHO } \\
\text { INS } \\
\text { GH }\end{array}$ & $\begin{array}{l}97 \\
1.0 \\
6\end{array}$ & $\begin{array}{c}315 \\
0.7 \\
7\end{array}$ & $\begin{array}{c}311 \\
0.7 \\
7\end{array}$ & & $\begin{array}{c}302 \\
0.8 \\
6\end{array}$ & $\begin{array}{c}265 \\
0.9 \\
7\end{array}$ & & & & $\begin{array}{l}14 \mathrm{hr} \text { of life, female } \\
0.46 \mathrm{~kg} \text {, fetal tolbu- } \\
\text { tamide injection }\end{array}$ \\
\hline $820 \mathrm{~N}$ & $\begin{array}{l}250 \mathrm{mg} \text { glucose in- } \\
\text { jected at } 0^{\prime}\end{array}$ & $\begin{array}{l}\text { Umbilical } \\
\text { vein }\end{array}$ & $\begin{array}{l}\text { CHO } \\
\text { INS } \\
\text { GH }\end{array}$ & $\begin{array}{l}92 \\
1.0 \\
5\end{array}$ & & & & & $\begin{array}{l}210 \\
1.4 \\
8\end{array}$ & $\begin{array}{c}150 \\
2.5 \\
11\end{array}$ & $\begin{array}{c}116 \\
2.2 \\
19\end{array}$ & $\begin{array}{l}90 \\
1.3 \\
28\end{array}$ & $\begin{array}{l}12 \mathrm{hr} \text { of life, female } \\
0.43 \mathrm{~kg}\end{array}$ \\
\hline $298 \mathrm{~N}$ & $\begin{array}{l}250 \mathrm{mg} \text { glucose in- } \\
\text { jected at } 0^{\prime}\end{array}$ & $\begin{array}{l}\text { Umbilical } \\
\text { vein }\end{array}$ & $\begin{array}{l}\text { CHO } \\
\text { INS } \\
\text { GH }\end{array}$ & $\begin{array}{c}53 \\
0.5 \\
12\end{array}$ & & & & & $\begin{array}{c}127 \\
2.3 \\
14\end{array}$ & $\begin{array}{c}114 \\
4.6 \\
23\end{array}$ & $\begin{array}{c}98 \\
4.2 \\
39\end{array}$ & $\begin{array}{l}72 \\
3.0 \\
40\end{array}$ & $\begin{array}{l}22 \mathrm{hr} \text { of life, male } 0.37 \\
\mathrm{~kg} \text {, fetal arginine } \\
\text { infusion }\end{array}$ \\
\hline
\end{tabular}

* Plasma glucose $\mathrm{mg} / 100 \mathrm{ml}$.

$\mp$ Plasma insulin $\mathrm{m} \mu \mathrm{g} / \mathrm{ml}$.

\& Plasma growth hormone $\mathrm{m} \mu \mathrm{g} / \mathrm{ml}$.

|| Immunoreactive growth hormone-like substance $\mathrm{m} \mu \mathrm{g} / \mathrm{ml}$.

nancy, a younger fetus (110 days) received an intravenous injection of $50 \mathrm{mg}$ tolbutamide $(637 \mathrm{C})$. The fetal plasma insulin concentration did not change. This fetus demonstrated progressive increases in fetal plasma glucose and growth hormone concentrations which were accompanied by the development of fetal bradycardia at $20 \mathrm{~min}$. The hematocrit of this fetus declined from $40 \%$ at the time of injection to $20 \%$ at $30 \mathrm{~min}$. 
TABLE III

Effect of Intravascular Arginine Infusion Into the Fetus or Neonate on the Plasma Glucose, Insulin, Growth Hormone, and Immunoreactive Growth Hormone-Like Concentrations

\begin{tabular}{|c|c|c|c|c|c|c|c|c|c|}
\hline \multirow[b]{2}{*}{ Animal } & \multirow[b]{2}{*}{ Amount } & \multirow[b]{2}{*}{ Site } & \multirow{2}{*}{$\begin{array}{l}\text { Plasma } \\
\text { assay }\end{array}$} & \multicolumn{5}{|c|}{ Time (min) } & \multirow[b]{2}{*}{ Comment } \\
\hline & & & & 0 & 15 & 30 & 45 & 60 & \\
\hline \multirow[t]{3}{*}{$642 \mathrm{C}$} & $\begin{array}{l}\text { Arginine, } 10 \mathrm{mg} / \mathrm{min} \\
\text { infused for } 30 \mathrm{~min}\end{array}$ & Fetal artery & $\begin{array}{l}\text { CHO* } \\
\text { INS }\end{array}$ & $\begin{array}{l}46 \\
0.6\end{array}$ & $\begin{array}{l}49 \\
0.6\end{array}$ & $\begin{array}{l}45 \\
0.5\end{array}$ & $\begin{array}{l}47 \\
0.7\end{array}$ & $\begin{array}{l}48 \\
0.6\end{array}$ & $\begin{array}{l}141 \text { day gestation } \\
\text { - mother } 7.9 \mathrm{~kg} \text {, male }\end{array}$ \\
\hline & & & GH§ & 14 & 12 & 10 & 10 & 12 & $\begin{array}{l}\text { fetus } 0.38 \mathrm{~kg} \text {, pla- } \\
\text { centa } 0.15 \mathrm{~kg}\end{array}$ \\
\hline & & $\begin{array}{l}\text { Maternal } \\
\text { vena cava }\end{array}$ & $\begin{array}{l}\text { CHO } \\
\text { INS } \\
\text { GHL\| }\end{array}$ & $\begin{array}{c}60 \\
0.7 \\
108\end{array}$ & $\begin{array}{l}62 \\
1.0 \\
110\end{array}$ & $\begin{array}{c}67 \\
1.0 \\
115\end{array}$ & $\begin{array}{c}64 \\
1.0 \\
109\end{array}$ & $\begin{array}{c}62 \\
0.9 \\
109\end{array}$ & \\
\hline \multirow[t]{2}{*}{$411 \mathrm{C}$} & $\begin{array}{l}\text { Arginine, } 10 \mathrm{mg} / \mathrm{min} \\
\text { infused for } 30 \mathrm{~min}\end{array}$ & Fetal artery & $\begin{array}{l}\text { CHO } \\
\text { INS } \\
\text { GH }\end{array}$ & $\begin{array}{l}46 \\
0.5 \\
17\end{array}$ & $\begin{array}{c}42 \\
0.6 \\
15\end{array}$ & $\begin{array}{l}42 \\
0.5 \\
14\end{array}$ & $\begin{array}{l}48 \\
0.6 \\
14\end{array}$ & $\begin{array}{l}46 \\
0.5 \\
15\end{array}$ & $\begin{array}{l}149 \text { day gestation, } \\
\text { mother } 8.5 \mathrm{~kg} \text {, male } \\
\text { fetus } 0.46 \mathrm{~kg} \text {, pla- } \\
\text { centa } 0.16 \mathrm{~kg}\end{array}$ \\
\hline & & $\begin{array}{l}\text { Maternal } \\
\text { vena cava }\end{array}$ & $\begin{array}{l}\text { CHO } \\
\text { INS } \\
\text { GHL }\end{array}$ & $\begin{array}{l}53 \\
2.0 \\
90\end{array}$ & $\begin{array}{l}51 \\
1.8 \\
88\end{array}$ & $\begin{array}{l}53 \\
2.1 \\
81\end{array}$ & $\begin{array}{l}56 \\
1.7 \\
84\end{array}$ & $\begin{array}{l}58 \\
1.9 \\
89\end{array}$ & \\
\hline \multirow[t]{4}{*}{$298 \mathrm{C}$} & $\begin{array}{l}\text { Arginine } 10 \mathrm{mg} / \mathrm{min} \\
\text { infused for } 30 \mathrm{~min}\end{array}$ & Fetal artery & $\begin{array}{l}\text { CHO } \\
\text { INS }\end{array}$ & $\begin{array}{c}56 \\
0.8\end{array}$ & $\begin{array}{l}61 \\
0.7\end{array}$ & $\begin{array}{l}72 \\
0.8\end{array}$ & $\begin{array}{c}76 \\
0.8\end{array}$ & $\begin{array}{l}98 \\
0.8\end{array}$ & $\begin{array}{l}142 \text { day gestation, } \\
\text { mother } 6.5 \mathrm{~kg} \text {, male }\end{array}$ \\
\hline & & & GH & 31 & 33 & 37 & 46 & 51 & \\
\hline & & $\begin{array}{l}\text { Maternal } \\
\text { vena cava }\end{array}$ & $\begin{array}{l}\text { CHO } \\
\text { INS }\end{array}$ & $\begin{array}{l}70 \\
3.3\end{array}$ & $\begin{array}{l}66 \\
3.7\end{array}$ & $\begin{array}{c}66 \\
3.1\end{array}$ & $\begin{array}{l}69 \\
3.4\end{array}$ & $\begin{array}{l}72 \\
2.6\end{array}$ & $\begin{array}{l}\text { ular uterine contrac- } \\
\text { tion beginning at } 30\end{array}$ \\
\hline & & & GHL & 96 & 90 & 92 & 96 & 96 & $\min$ \\
\hline $642 \mathrm{~N}$ & $\begin{array}{l}\text { Arginine, } 10 \mathrm{mg} / \mathrm{min} \\
\text { infused for } 30 \mathrm{~min}\end{array}$ & $\begin{array}{l}\text { Umbilical } \\
\text { vein }\end{array}$ & $\begin{array}{l}\text { CHO } \\
\text { INS } \\
\text { GH }\end{array}$ & $\begin{array}{l}50 \\
0.7 \\
3\end{array}$ & $\begin{array}{l}50 \\
0.6 \\
2\end{array}$ & $\begin{array}{l}48 \\
0.7 \\
2\end{array}$ & $\begin{array}{l}52 \\
0.6 \\
4\end{array}$ & $\begin{array}{l}50 \\
0.7 \\
5\end{array}$ & $\begin{array}{l}12 \mathrm{hr} \text { of life, male } 0.37 \\
\mathrm{~kg} \text {, fetal arginine in- } \\
\text { fusion }\end{array}$ \\
\hline $962 \mathrm{~N}$ & $\begin{array}{l}\text { Arginine, } 10 \mathrm{mg} / \mathrm{min} \\
\text { infused for } 30 \mathrm{~min}\end{array}$ & $\begin{array}{l}\text { Umbilical } \\
\text { vein }\end{array}$ & $\begin{array}{l}\text { CHO } \\
\text { INS } \\
\text { GH }\end{array}$ & $\begin{array}{l}45 \\
1.1 \\
8\end{array}$ & $\begin{array}{l}49 \\
1.2 \\
9\end{array}$ & $\begin{array}{l}47 \\
11.0 \\
11\end{array}$ & $\begin{array}{l}49 \\
1.0 \\
12\end{array}$ & $\begin{array}{l}50 \\
1.0 \\
10\end{array}$ & $4 \mathrm{hr}$ of life, male $0.34 \mathrm{~kg}$ \\
\hline
\end{tabular}

* Plasma glucose $\mathrm{mg} / 100 \mathrm{ml}$.

$\ddagger$ Plasma insulin $\mathrm{m} \mu \mathrm{g} / \mathrm{ml}$.

$\S$ Plasma growth hormone $\mathrm{m} \mu \mathrm{g} / \mathrm{ml}$.

|| Immunoreactive growth hormone-like substance $\mathrm{m} \mu \mathrm{g} / \mathrm{ml}$.

The injection of tolbutamide evoked an immediate 4to 8-fold increase in the insulin concentration of the plasma of two neonates (Table IV, $411 \mathrm{~N}, 283 \mathrm{~N}$ ). These neonates did not respond to arginine or sustained glucose infusions when treated in utero (Tables II and III). In experiment $411 \mathrm{~N}$, an increase in plasma glucose and growth hormone levels occurred at the termination of the experiment. In contrast, the plasma glucose concentration fell in neonate $283 \mathrm{~N}$ while plasma growth hormone levels were unchanged.

\section{DISCUSSION}

A bidirectional transfer of radioisotopically labeled porcine insulin was found. The characteristics of the ma- ternal to fetal transfer suggest the presence of a relative barrier and are consistent with the data of Josimovich and Knobil (19) obtained from pregnant rhesus monkeys of 107-129 days gestation. The extent of this relative placental impermeability to the undirectional maternalfetal transfer of insulin has not been resolved in humans $(20,21)$.

We found a limited fetal to maternal transfer of insulin- ${ }^{181} I$ in our experiments as did Josimovich and Knobil (19). The use of a $\mathrm{T}$ tube in the interplacental vessel permitted uninterrupted fetal blood flow to and from the placenta and eliminated variations in placental blood flow that may have compounded interpretation of their single experiment. The fact that insulin crossed 
TABLE IV

Effect of Intravenous Tolbutamide Administration to the Fetus or Neonate on the Plamsa Glucose, Insulin, Growth Hormone, and Immunoreactive Growth Hormone-like Concentrations

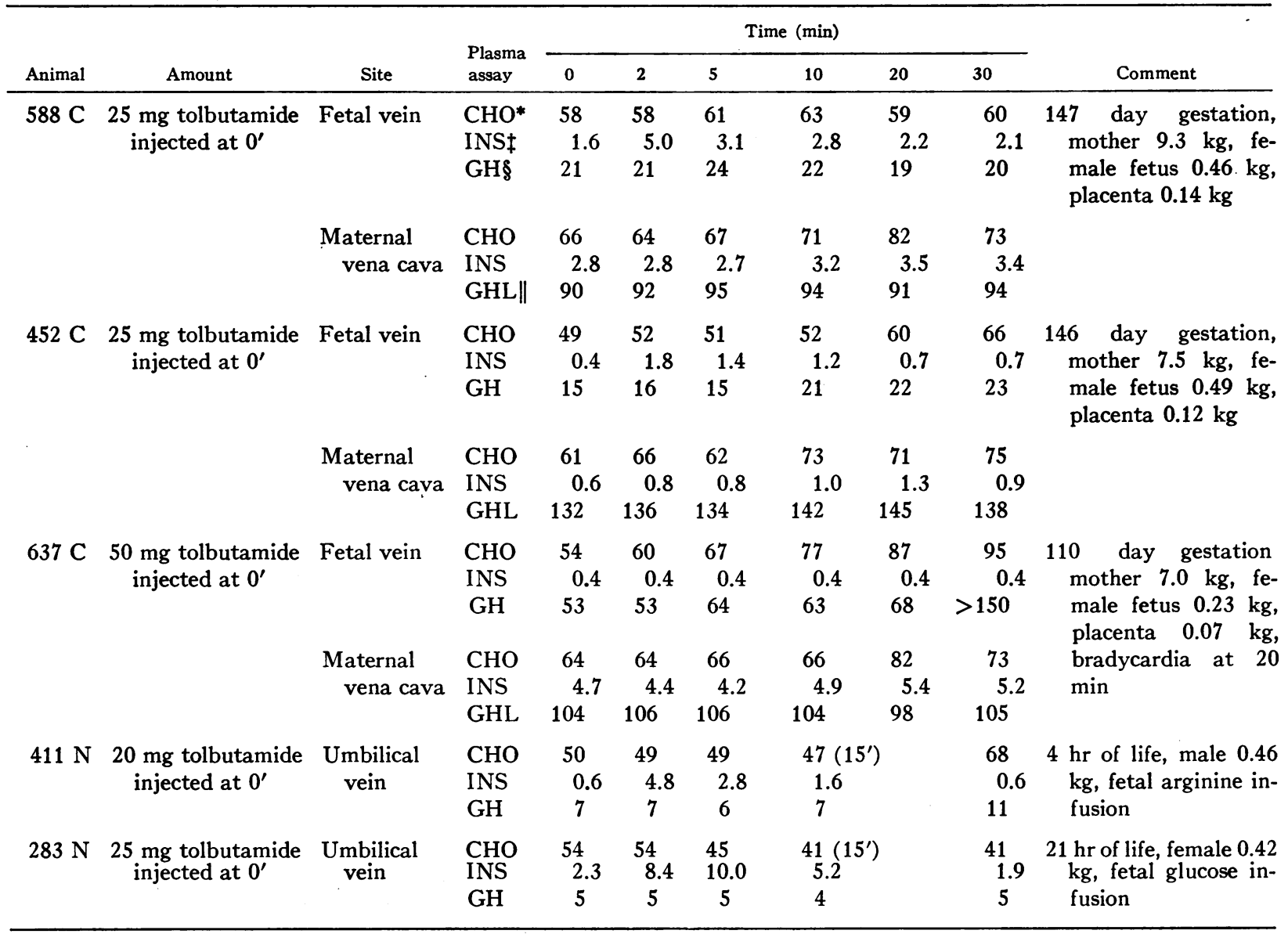

* Plasma glucose $\mathrm{mg} / 100 \mathrm{ml}$.

$\ddagger$ Plasma insulin $\mathrm{m} \mu \mathrm{g} / \mathrm{ml}$.

\&lasma growth hormone $\mathrm{m} \mu \mathrm{g} / \mathrm{ml}$.

II Immunoreactive growth hormone-like substance $\mathrm{m} \mu \mathrm{g} / \mathrm{ml}$.

against an immunoassayable insulin concentration gradient need not imply an active transfer mechanism. This transfer is also consistent with simple exchange secondary to the driving force of the labeled substrate's concentration gradient before it reaches pool equilibrium.

These transfer experiments are only qualitative in nature. We did not measure blood flow, blood volumes, or changes in specific activity; nor can we evaluate maternal, fetal, and placental degradation, sequestration, binding, and release of insulin. These multiple and unmeasured variables obviate a valid quantitative comment about insulin transfer and exchange. Furthermore, although insulin does cross the primate placenta bidirectionally, the physiologic circumstances as well as the mechanisms by which crossing occurs remain undefined.
Insulin has been demonstrated in human fetal pancreatic islet tissue as early as the 15 th week of gestation $(22,23)$. Augmented insulin responses to intravenous glucose in newborns of diabetic mothers have been interpreted to indicate that elevated concentrations of fetal plasma glucose may increase insulin synthesis or release from fetal islet tissue $(1,5)$. Milner and Hales (4) injected glucose to mothers in labor and observed increased umbilical cord insulin concentrations at birth. They concluded that the pancreatic islets at term are functionally competent, but a maternal source for the cord insulin concentration changes cannot be excluded. There remains no direct antenatal evidence of glucose-mediated insulin release from primate fetal islet tissue.

In the present experiments, fetal plasma insulin con- 
centrations did not change in response to exogenous glucose stimulation. In the single injection experiments, rapid fetal to maternal transfer of the glucose may have limited the duration of the glycemic stimulation to the fetal pancreatic islets. However, fetal plasma insulin levels did not change during the $2 \mathrm{hr}$ fetal glucose infusions. This is in contrast to the neonate where plasma glucose concentrations similar to those obtained with the fetal infusion were associated with a delayed rise in plasma insulin concentration. Delayed plasma insulin responses to intravenous glucose in human neonates have also been observed $(5,24)$.

Arginine infusions did not affect plasma insulin concentrations in either the fetus or the neonate. Nonpregnant adult monkeys given $0.5 \mathrm{gm} / \mathrm{kg}$ of arginine by infusion for $30 \mathrm{~min}$ do respond with acute elevations of plasma insulin levels. ${ }^{1}$ With the exception of experiment $298 \mathrm{C}$, in which uterine contractions may have affected plasma glucose concentration, the fetal and neonatal plasma glucose levels remained unchanged during the arginine infusion. These observations are consistent with the hypothesis that utilization of amino acids by the fetus is primarily directed at the synthesis of proteins, rather than at gluconeogenesis (25).

In contrast to the apparent unresponsiveness of the fetal pancreatic islet cells to the insulinogenic actions of glucose and arginine, tolbutamide which releases insulin by a mechanism differing from glucose (26), induced a prompt increase in plasma insulin concentration in both the more mature fetuses and in the neonates. The absence of an insulin response to tolbutamide earlier in pregnancy (experiment $637 \mathrm{C}$, equivalent in time to a 28 week human gestation) is considered inconclusive because of fetal distress during the experiment. Despite the 3 to 4 -fold increase in fetal plasma insulin concentration at 2 min after the tolbutamide injection, the fetal plasma glucose concentration did not fall. This apparent intrauterine insulin resistance may exist as a primary fetal protective mechanism against fetal hypoglycemia. However, rapid placental transfer of glucose to the fetus from the relatively large maternal pool of glucose could also account for these observations. Since tolbutamide is transferred across the human placenta (27), further studies may reveal whether a modification of fetal pancreatic islet cell function results from administration of this agent to pregnant humans.

During pregnancy, the fetus receives a continuous supply of glucose from its mother and this has been assumed to be its principle metabolic fuel (25). The failure of fetal plasma insulin concentration to rise after glucose administration suggests that fetal carbohydrate metabolism may include certain unique features. Since the near term fetus accumulates large reserves

1 Chez, R. A. and D. H. Mintz. Unpublished observations. of carbohydrate in its liver and skeletal muscles (28), glucose uptake by these tissues is either insulin independent or is efficiently accomplished by the basal concentrations of insulin in fetal plasma. However, evidence in the chick embryo and therefore of uncertain significance for primate fetuses does indicate that as pregnancy progresses, glucose uptake by heart tissue is limited by an insulin-sensitive barrier (29). After carbohydrate ingestion in human adults, the rapid release of insulin facilitates plasma glucose homeostasis. The fetus may not require a similar insulin response if fetal plasma glucose concentrations are a direct function of the resultant maternal plasma glucose levels. In any event, explanations for our observations must incorporate mechanisms for both the unresponsiveness of fetal pancreatic islet tissue to glucose and the appearance of islet cell responsiveness in early neonatal life.

Human growth hormone has been detected in fetal pituitary tissue at 8 weeks gestation (30), and elevated levels of human growth hormone have been found in the plasma from aborted fetuses (31) and from umbilical cord (6-9). In the radioimmunoassay system employed in the present studies, simian fetal plasma contained a substance which reacted with immunologic identity to human growth hormone. In contrast, simian maternal plasma and amniotic fluid reacted with nonidentity, presumably due to their content of placental lactogen (32).

The initial concentrations of fetal plasma growth hormone in these experiments $(25 \mathrm{~m} \mu \mathrm{g} / \mathrm{ml} \pm 12$, mean $\pm \mathrm{SD})$ are significantly elevated $(P<0.001)$ when contrasted to the initial plasma levels observed in the neonate $(7 \mathrm{~m} \mu \mathrm{g} / \mathrm{ml} \pm 3)$. These data may indicate that a change in growth hormone metabolism occurs from fetal to neonatal life. The low simian neonatal level also contrasts with the level recorded for human cord blood at delivery (6-9) and the mean plasma growth hormone concentration of $52 \mathrm{~m} \mu \mathrm{g} / \mathrm{ml}$ (range 9-167 $\mathrm{m} \mu \mathrm{g} / \mathrm{ml}$ ) found by Cornblath, Parker, Reisner, Forbes, and Daughaday (6) in human newborns during the first 24 hr of life. Whether this concentration difference between the human and monkey neonate is due to species variations or to differences in the basal state of the subjects during the study remains to be determined. The study conditions may also influence the simian neonatalfetal concentration difference. Chronic cannulation of fetal vessels over several days would be one way to clarify the basal fetal plasma growth hormone levels independent of any adverse effect of surgery. To do so with this model, technical problems regarding cannula clotting and animal mobility will have to be overcome.

There was no difference in the responsiveness of the growth hormone-releasing mechanism between the simian fetus and neonate when challenged by glucose or arginine infusion. Unlike plasma growth hormone re- 
sponses in human adolescents $(6,33)$ and adult (34 $36)$, glucose administration did not suppress nor did arginine infusion consistently augment fetal or neonatal plasma growth hormone levels. The failure of hyperglycemia to inhibit pituitary release of growth hormone in human premature and newborn infants has been previously observed (6).

Independent of the test solution injected, an elevation of plasma growth hormone was observed near or at the time of the terminal blood samples in many of the present experiments. This is particularly evident in an experiment on a fetus early in gestation (Table IV, 637C) in which a fall in hematocrit of $50 \%$ was accompanied by fetal bradycardia and reversal of the maternal to fetal glucose gradient. Meyer and Knobil (17) described a variety of stimuli, including acute changes in blood volume, which can elicit the secretion of growth hormone in the adult nonpregnant rhesus monkey. A paradoxical increase in plasma growth hormone concentration after intravenous glucose has been described in human newborns (6). Whether the terminal elevation of plasma growth hormone levels after glucose administration in the present experiments represent a similar paradoxical response or a nonspecific response to the stress of the procedure (34) cannot be distinguished. The increasing availability of radioimmunoassay and other techniques requiring small aliquots of blood as well as refinements in surgical techniques will continue to provide.opportunities to clarify this and other aspects of fetal endocrine physiology.

\section{ACKNOWLEDGMENTS}

We are indebted to Mrs. Constance Boyle, Mrs. Katherine McDade, and Miss Janet Volkin for their excellent technical assistance. We gratefully acknowledge the assistance of Dr. David Valerio, D.V.M. from the Bionetics Research Laboratories, Kensington, Md., during the surgical sessions and in the care of the newborns.

This work was supported by the Health Research and Service Foundation of Pittsburgh, Grant No. H33; National Institutes of Health, Grant No. AM-10940 and Grant No. HD-03155; and the General Research Support Grant No. 5801 FR05570 from the U. S. Public Health Service. Dr. Horger is U. S. Public Health Service Research Fellow No. 1 F3 HD-35, 200-01, from the National Institute of Child Health and Human Development.

\section{REFERENCES}

1. Baird, J. D., and J. W. Farquhar. 1962. The insulin secreting capacity of the pancreas in newborn infants of normal and diabetic women. Lancet. 1: 71.

2. Spellacy, W. N., F. C. Goetz, B. Z. Greenberg, and J. Ellis. 1964. The human placental gradient for plasma insulin and blood glucose. Amer. J. Obstet. Gynecol. 90: 753.

3. Stimmer, L., J. V. Brozie, and D. O'Brien. 1964. Plasmainsulin levels in the newborn infants of normal and diabetic mothers. Lancet. 1: 137.
4. Milner, R. D. G., and C. N. Hales. 1965. Effect of intravenous glucose on concentration of insulin in maternal and umbilical cord plasma. Brit. Med. J. 1: 284.

5. Jorgenson, K., T. Dickert, L. M. Pederson, and J. Pederson. 1966. Plasma insulin, insulin-secretory capacity and insulin antibodies in newborn infants of diabetic women. Acta Endocrinol. 52: 154.

6. Cornblath, M., M. L. Parker, S. H. Reisner, A. E. Forbes, and W. H. Daughaday. 1965. Secretion and metabolism of growth hormone in premature and fullterm infants. J. Clin. Endocrinol. Metab. 25: 209.

7. Greenwood, F. C., W. M. Hunter, and A. Klopper. 1964. Assay of human growth hormone in pregnancy at parturition and in lactation. Detection of a growth hormonelike substance from the placenta. Brit. Med. J. 1: 22.

8. Glick, S. M., J. Roth, R. S. Yalow, and S. Berson. 1963. Immunoassay of human growth hormone in plasma. Nature (London). 199: 784.

9. Kaplan, S. L., and M. M. Grumbach. 1965. Serum chorionic "growth hormone-prolactin" and serum pituitary growth hormone in mother and fetus at term. J. Clin. Endocrinol. Metab. 25: 1370.

10. Reynolds, S. R. M., W. M. Paul, and A. St. G. Huggett. 1954. Physiological study of the monkey fetus in utero: a procedure for blood pressure recording, blood sampling, and injection of the fetus under normal conditions. Bull. Johns Hopkins Hosp. 95: 256.

11. Friedman, E. A., M. J. Gray, M. Grynfogel, D. L. Hutchinson, W. T. Kelly, and A. A. Plentl. 1960. Distribution and metabolism of C-14-labeled lactic acid and bicarbonate in pregnant primates. J. Clin. Invest. 39: 227.

12. Hutchinson, D. L., W. T. Kelly, E. A. Friedman, and A. A. Plentl. 1962. The distribution and metabolism of carbon-labeled urea in pregnant primates. J. Clin. Invest. $41: 1745$.

13. Plentl, A. A., and E. A. Friednian. 1962. Isotope trace studies on the carbon dioxide exchange in pregnant primates. Amer. J. Obstet. Gynecol. 84: 1242.

14. Hunter, W. M., and F. C. Greenwood. 1962. Preparation of iodine-131 labeled human growth hormone of high specific activity. Nature (London). 194: 495.

15. Yalow, R. S., and S. A. Berson. 1960. Immunoassay of endogenous plasma insulin in man. J. Clin. Invest. 39: 1157.

16. Morgan, C. R., and A. Lazarow. 1963. Immunoassay of insulin: two antibody system. Plasma insulin levels of normal, subdiabetic and diabetic rats. Diabetes. 12: 115.

17. Meyer, V., and E. Knobil. 1967. Growth hormone in unanesthetized rhesus monkeys in response to noxious stimuli. Endocrinology. 80: 163.

18. Herbert, V., L. Kam-Seng, C. W. Gottlieb, and S. J. Bleicher. 1965. Coated charcoal immunoassay of insulin. J. Clin. Endocrinol. Metab. 25: 1375.

19. Josimovich, J. B., and E. Knobil. 1961. Placental transfer of $\mathrm{I}^{131}$ insulin in the rhesus monkey. Amer. J. Physiol. 200: 471 .

20. Buse, M. G., W. J. Roberts, and J. Buse. 1962. The role of the human placenta in the transfer and metabolism of insulin. J. Clin. Invest. 41: 29.

21. Gitlin, D., J. Kumate, and C. Morales. 1965. On the transport of insulin across the human placenta. Pediatrics. $35: 65$.

22. Conklin, J. 1962. Cytogenesis of the human fetal pancreas. Amer. J. Anat. 3: 181.

23. Steinke, J., and S. G. Driscoll. 1963. The extractable insulin content of pancreas from fetus and infants of diabetic and control members. Diabetes. 14: 573. 
24. Spellacy, W. N., S. A. Gall, and K. L. Carlson. 1967. Carbohydrate metabolism of the normal term newborn: plasma insulin and blood glucose levels during an intravenous glucose tolerance test. Amer. J. Obstet. Gynecol. 30: 580 .

25. Dawes, G. S. 1968. A comparative study of the changes at birth. In Foetal and Neonatal Physiology. Year Book Medical Publishers Inc., Chicago. 1st edition.

26. Seltzer, H. S. 1962. Quantitative effects of glucose sulfonylurea, salacyate, and indole-3-acetic acid on the secretion of insulin activity into pancreatic venous blood. J. Clin. Invest. 41 : 289.

27. Miller, D. I., H. Wishinsky, and G. Thompson. 1962. Transfer of tolbutamide across the human placenta. Diabetes. 11: 93.

28. Shelly, H. J. 1961. Glycogen reserves and their changes at birth. Brit. Med. Bull. $22: 34$.

29. Guidotti, G., D. Kanameishi, and P. P. Foa. 1961. Chick embryo heart as a tool for studying cell permeability and insulin action. Amer. J. Physiol. 201: 863.

30. Matsuzaki, F., and K. Shizume. 1968. Growth hormone in human fetuses. Excerpta Med. Int. Congr. Ser. 157: 19 (Abstr.)
31. Kaplan, S. L., and M. M. Grumbach. 1968. Growth hormone secretion in the human fetus and in anencephaly. Pediat. Res. 1: 308 (Abstr.)

32. Josimovich, J. 1968. Clinical Endocrinology. E. B. Astwood and C. E. Cassidy, editors. Grune and Stratton, New York. 658-666.

33. Drash, A., J. B. Field, L. Y. Garces, F. M. Kenney, D. Mintz, and A. M. Vazquez. 1968. Endogenous insulin and growth hormone response in children with newly diagnosed diabetes mellitus. Pediat. Res. 2: 94.

34. Glick, S. M., J. Roth, R. S. Yalow, and S. A. Berson. 1965. The regulation of growth hormone secretion. In Recent Progress in Hormone Research, Pincus, G., editors. Academic Press, Inc. New York. 21: 241-283.

35. Knopf, R. F., J. W. Conn, S. S. Fajans, J. C. Floyd, E. M. Gunstsche, and J. A. Rull. 1965. Plasma growth hormone response to intravenous administration of amino acids. J. Clin. Endocrinol. 25: 1140.

36. Rabinowitz, D., T. J. Merimee, D. A. Burgess, and L. Riggs. 1966. Growth hormone and insulin release after arginine: indifference to hyperglycemia and epinephrine. J. Clin. Endocrinol. 26: 1170. 